\title{
Infanticídio indígena no Brasil: o conflito entre o direito à vida e à liberdade cultural e religiosa dos povos indígenas
}

\section{Indigenous infanticide in Brazil: the conflict between the right to life and cultural and religious freedom of indigenous people}

\author{
Marcus Mendonça Gonçalves de Jesus* \\ Erick Wilson Pereira*
}

\section{Resumo}

Este trabalho tem o intuito de analisar o conflito entre princípios constitucionais que permeiam a prática do infanticídio indígena no Brasil, uma vez que há um impasse entre o direito à vida, de um lado, e, por outro lado, o direito dos povos indígenas se autodeterminarem em suas terras, conservando suas crenças, costumes e cultura. A existência dessa prática nos dias de hoje provoca indignação nos setores da sociedade e em estudiosos do direito, que defendem o direito à vida como um elemento acima de qualquer outro direito. Entretanto, os povos nativos que permitem o infanticídio mantêm um costume secular que antecede a formação de um aparelho estatal no Brasil e também tais agentes não compartilham dos mesmos valores morais daqueles que condenam a prática. Com isso, surge a necessidade de se discutir, levando em consideração as disposições da Constituição Federal de 1988 e a realidade histórico-cultural dos autóctones, se há pertinência em proibir o infanticídio ou permitir que ele continue.

Palavras-chave: Infanticídio indígena. Direito à vida. Liberdade cultural. Costumes. Constituição Federal de 1988.

Mestrando em direito constitucional pela Universidade Federal do Rio Grande do Norte. Natal RN - Brasil. E-mail: marcusmgjesus@gmail.com.

* Advogado e professor doutor na Universidade Federal do Rio Grande do Norte em turmas de graduação e mestrado. Natal - RN - Brasil. E-mail: ewp@erickpereira.adv.br. 


\section{Abstract}

This work aims to analyze the conflict between constitutional principles that underlie the practice of indigenous infanticide in Brazil, since there is an impasse between the right to life, on the one hand, and on the other hand, the right of indigenous people to determine themselves on their land, preserving their beliefs, customs and culture. The existence of this practice nowadays causes indignation in the sectors of society and legal scholars who defend the right to life as an element above any other law. However, the native peoples that allow infanticide maintain a secular custom preceding the formation of a state apparatus in Brazil and also such agents do not share the same moral values of those who condemn the practice. With that comes the need to discuss, taking into account the provisions of the Federal Constitution of 1988 and the historical and cultural situation of indigenous, if there is relevance to prohibit infanticide or allow it to continue.

Keywords: Indigenous infanticide. Right to life. Cultural freedom. Customs. Federal Constitution of 1988.

\section{Introdução}

O presente artigo tem como objetivo discutir acerca do conflito existente entre princípios constitucionais e direitos humanos fundamentais em relação à prática do infanticídio em algumas tribos indígenas no Brasil, situação que precisa ser mais analisada e discutida, tanto no âmbito jurídico como no âmbito midiático.

O fato de um ser humano tirar deliberadamente a vida de outro é um ato que pode ser considerado contrário à moral, aos costumes e às crenças religiosas dos mais diversos povos, em diferentes lugares e épocas. Por outro lado, diferentes povos também flexibilizam a possibilidade de um indivíduo extinguir a vida de outro, como, por exemplo, nos casos de países que permitem o aborto, a eutanásia e/ou a pena de morte.

No que tange à prática do infanticídio indígena no Brasil, levase em consideração que tal ato já era praticado por várias tribos antes 
mesmo da chegada dos europeus ao continente americano. Paralelo a isso, o país é regido pela Constituição Federal de 1988, que, entre tantos valores, coloca o direito à vida como principal entre os direitos humanos fundamentais (art. $5^{\circ}$ ). Sendo assim, o infanticídio indígena, que é praticado com certos objetivos e em casos específicos, choca e comove outra parte da sociedade, com outras crenças e costumes, a qual considera o ato intolerável e que precisa ser suprimido.

As mais diversas etnias indígenas do território brasileiro sofreram inúmeras formas de opressão desde o período colonial, sendo obrigados a aderir a hábitos e práticas religiosas dos europeus, bem como várias delas foram escravizadas, dizimadas e expulsas de suas terras. No entanto, com o avanço das ideias democráticas no país, os nativos foram conquistando reconhecimento e direitos, o que se manifesta na Constituição atual (art. 231 e 232), oferecendo-lhes a faculdade de se autodeterminarem em suas terras e recebendo proteção para suas práticas culturais e religiosas.

Em contraposição ao que foi exposto no parágrafo anterior, algumas pessoas defendem que os indígenas, mesmo recebendo atenção especial pela Constituição Federal de 1988, estão sujeitos às mesmas disposições normativas que qualquer outro cidadão brasileiro e a prática do infanticídio seria uma afronta a valores sociais tão prezados pela coletividade.

Sendo assim, este trabalho trará a ponderação sobre até onde vai a proteção à vida e a proteção à autonomia dos povos indígenas brasileiros. Para tanto, utilizar-se-á de análise doutrinária sobre a colisão de direitos humanos fundamentais, dos princípios constitucionais e da legislação.

Haverá uma explanação histórica a respeito do tratamento normativo que os indígenas têm recebido, seja nas Constituições Federais, seja nas Leis do país, e como se deram as conquistas de direitos e o reconhecimento desses povos como dignos de proteção do Estado. Bem como, será exibido o panorama da prática do infanticídio indígena no país atualmente, os locais onde ocorre e as razões pela qual ocorre. Nesse mesmo capítulo, será verificada a inclusão dos 
casos específicos nas estatísticas do Mapa da Violência 2014, até então desconsiderados.

Destarte, é pertinente que sejam expostas as características dos crimes de homicídio, infanticídio e de abandono de incapaz, nos seus aspectos formais e materiais, bem como o tratamento dado aos silvícolas pelo Código Penal, e a análise pertinente à existência ou não de ilicitude, tipicidade e/ou culpabilidade na prática dos nativos, segundo a doutrina jurídica. Incluindo-se aí a possibilidade de a prática configurar-se como homicídio qualificado.

Outrossim, será abordado o Princípio da Proteção Integral da Criança, previsto constitucionalmente e consolidado pela Convenção sobre os Direitos da Criança e pelo Estatuto da Criança e do Adolescente (ECA), que, dadas às vulnerabilidades físicas e psicológicas dessa faixa etária, o Estado acaba por oferecer proteção especial a esse grupo. Com isso, será discutido se a vida de uma criança indefesa pode ser extinta em razão de uma prática cultural ainda que os motivos que induzam a essa prática sejam tidos como justificáveis por aqueles que a fazem.

Também será feita a análise acerca da colisão de direitos humanos fundamentais que existe nos casos de infanticídio indígena. Sendo assim, serão sopesados os direitos em questão e será ponderado sobre se deve prevalecer o direito à vida ou o direito às manifestações culturais indígenas. Junto a essas colocações, será verificada se há pertinência na proibição dessa prática para atender aos valores sociais presentes na maioria da população em confronto ao respeito às minorias no Estado Democrático de Direito.

Este trabalho conta com apoio e financiamento da Coordenação de Aperfeiçoamento de Pessoal de Nível Superior (CAPES) por meio de bolsa de pesquisa para mestrado.

\section{Histórico do tratamento constitucional e legal às práticas indígenas no Brasil}

Em nível constitucional, a Constituição Federal de 1891 foi omissa quanto a garantir qualquer proteção aos índios, seus costumes e suas 
terras. Apenas com a Constituição de 1934, art. 129, é que houve um avanço no sentido de proteger algum direito indígena, sendo garantida a posse das terras pelos silvícolas que nelas se encontrassem e sendo vedado aliená-las. A Constituição de 1937 manteve essa mesma disposição em seu artigo 154. A Constituição de 1946 também não fez nenhuma alteração significativa no que se refere a todos os aspectos da vida dos indígenas, permanecendo a previsão de que os silvícolas tinham direito à posse de suas terras e não podiam transferi-las, por nenhuma razão, como enunciava o art. 216.

Chegando ao período do Regime Militar, a Constituição Federal de 1967, em seu art. 186, trouxe um avanço no sentido de não apenas garantir a posse das terras pelos silvícolas que nelas habitassem, mas também garantir a esses povos a exclusividade no usufruto dos recursos naturais e de todas as outras utilidades que existissem nessas terras. Por sua vez, a Emenda Constitucional $n^{0} 1$, de 1969, foi além na proteção da posse das terras silvícolas, pois, em seu art. 198, garantia que as áreas em que eles habitassem não poderiam ser alienadas nos termos que a lei federal determinasse. Além disso, a mesma emenda declarava a nulidade e a extinção dos efeitos jurídicos concernentes ao domínio, à posse ou à ocupação das terras dos nativos, não sendo cabível nenhuma ação ou indenização para ocupantes indevidos.

A Lei Federal $n^{\circ} 6.001 / 1973$ trouxe grandes avanços para o âmbito indígena ao protegê-los não só em relação à posse das terras que habitavam, mas também em relação as suas tradições, prevendo ainda o exercício de direitos civis e políticos, bem como a tutela da União sobre eles.

Analisando a história das constituições do Brasil, vê-se que o máximo de garantia que os povos autóctones receberam foi em relação à posse de suas terras, não havendo tutela em relação a sua cultura e seus costumes. Esse progresso só se configurou na Constituição Federal de 1988, que não somente corroborou com a inalienabilidade das terras em que habitam, mas também conferiu a eles o rol de direitos sociais, civis e políticos dos quais todos os cidadãos brasileiros são titulares. 


\section{Aspectos históricos e culturais das práticas indígenas}

Antes de haver qualquer consideração jurídica acerca do infanticídio indígena, deve-se compreendê-lo como uma prática cultural e secular de alguns povos autóctones do Brasil. Quando os portugueses chegaram a terras brasileiras, encontraram uma população bastante homogênea segundo afinidades culturais e linguísticas, que, por sua vez, subdividia-se em dois grandes grupos: os tupis-guaranis e os tapuias. No entanto, havia outros grupos. As qualificações que viajantes, cronistas e padres, sobretudo os jesuítas, davam a cada grupo derivavam de quanto cada um deles resistia ao domínio português (FAUSTO, 2010, p. 37-38). Considera-se que há uma tendência em se desqualificar os comportamentos daqueles que agem fora dos padrões dominantes em uma sociedade, pois tais comportamentos geralmente são analisados segundo a herança cultural do observador (LARAIA, 1932, p. 67).

Sendo assim, as práticas indígenas foram maculadas desde então pelos dominadores portugueses, os quais impuseram seus costumes e crenças, de forma que muitos nativos tiveram aspectos de sua cultura banidos e inferiorizados nos registros europeus, ao mesmo tempo em que alguns dos povos indígenas conseguiram estabelecer relações amistosas com o povo colonizador com vistas à obtenção de benefícios mútuos, mas que giravam em torno dos interesses portugueses. Concernente a isso:

Profundo conhecedor da Amazônia setecentista, o jesuíta João Daniel tirava argumento da tibieza do poder do chefe tribal para justificar a administração dos indígenas pelos missionários. Segundo ele, sem os padres na diretoria dos aldeamentos as autoridades coloniais não poderiam implementar as ordens régias atinentes aos indígenas. Desprovidos de poder efetivo, os chefes nativos não conseguiam transmitir nem executar tais ordens (ALENCASTRO, 2000, p. 118).

A cultura representa, a rigor, um conjunto de práticas e conhecimentos acumulativos que permitiram ao homem se adaptar 
aos diferentes ambientes ecológicos, influenciando os comportamentos e justificando as realizações dele, caso sejam tomadas por base as concepções de Alfred Kroeber (LARAIA, 1932, p. 48-49). A cultura é estudada pela antropologia, a qual ganhou legitimidade científica na segunda metade do século XIX, em que toma para si, como objetos empíricos autônomos, os povos considerados primitivos, não correlacionados aos povos europeus e norte-americanos (LAPLANTINE, 2000 , p. 14). Assim, fica para o antropólogo a função de fazer a interpretação antropológica:

Olhar as dimensões simbólicas da ação social - arte, religião, ideologia, ciência, lei, moralidade, senso comum não é afastar-se dos dilemas existenciais da vida em favor de algum domínio empírico de formas não-emocionalizadas; é mergulhar no meio delas. A vocação essencial da antropologia interpretativa não é responder às nossas questões mais profundas, mas colocar à nossa disposição as respostas que outros deram - apascentando outros carneiros em outros vales - e assim incluí-las nos registros de consultas sobre o que o homem falou (GEERTZ, 2008, p. 21).

No período colonial, eram comuns os casos de abandonos de filhos, principalmente no meio urbano, pelas suas genitoras, quando se viam obstadas em assumir e sustentar filhos legítimos ou bastardos, configurando-se em um problema que preocupava eclesiásticos e administradores da colônia. Em um primeiro momento, as epidemias trazidas pelos portugueses, a fome e os conflitos com os colonizadores dizimaram muitos índios, fato que deixou muitos órfãos e, por sua vez, levou os jesuítas a criarem os colégios de meninos com o fito de abrigar e cuidar dos pequenos indígenas. Em momento posterior, no século XVII, o abandono de crianças começou a ser verificado na população de origem portuguesa, no contexto de crescimento econômico e populacional de muitas vilas e cidades (VENÂNCIO, 2007, p. 189-190), quando o Estado e a Administração colonial mostravam-se muito diferentes da atual imagem que se tem do Estado (LOPES, 2014, p. 222). 
Mais especificamente sobre a prática do infanticídio, sua execução em meio a povos indígenas da América do Sul verificava-se pelo fato de o nascimento de uma criança envolver "uma série de preceitos supersticiosos e de sobrevivência do grupo, em que prevaleciam os interesses coletivos sobre os individuais" (COLAÇO, 1998, p. 129). Por outro lado, sabe-se que o infanticídio não era ligado somente aos povos indígenas, sendo associado também a bruxas, e provocavam um temor no imaginário coletivo do Brasil Colônia, assim como na Europa (SOUZA, 1986, p. 201-204).

Diante das informações expostas, vê-se que o infanticídio e o abandono de crianças não se limitavam às terras indígenas, e que ocorria em meio aos descendentes dos portugueses, porém é necessário considerar que as motivações para as duas etnias eram diferentes. De todo modo, provocava repugnância em uma parcela da população do Brasil colonial.

\section{0 infanticídio indígena na atualidade}

O infanticídio era disseminado por vários povos indígenas da América Pré-colonial, como os lengua, para os quais "o ideal era que os filhos nascessem com um intervalo de 7 a 8 anos, para garantir a vida das crianças até esta idade, quando seriam mais resistentes e independentes" (COLAÇO, 1998, p. 129).

No caso do Brasil atual, os números referentes a casos de infanticídio indígena permaneceram uma incógnita até pouco tempo atrás, já que não eram computados nas estatísticas de violência e de saúde pública, e, por isso mesmo, ficavam desconhecidos para a maior parte da sociedade. A prática pode ser motivada pelo fato de a criança nascer com alguma deficiência física (em caso de nascimento de gêmeos), filho de mãe solteira, ou gerado em uma relação de adultério, por exemplo (TRADIÇÃO..., 2014, online).

A cultura indígena não é homogênea, de forma que cada etnia e cada tribo apresentam suas peculiaridades, tanto é que alguns 
desses povos permitem a prática do infanticídio, outros não. De acordo com os dados do censo 2010 do Instituto Brasileiro de Geografia e Estatística (IBGE), há 896 mil indígenas em todo o território nacional. Desse número, 572 mil $(63,8 \%)$ viviam na área rural e 517 mil $(57,5 \%)$ moravam em terras indígenas oficialmente reconhecidas, divididos em um pouco mais de 300 etnias e concentrados, em sua maioria, na região Norte (FUNAI). Sabe-se que a prática do infanticídio está presente em etnias como: uaiuai, bororo, mehinaco, tapirapé, ticuna, amondaua, uru-eu-uau-uau, suruwaha, deni, jarawara, jaminawa, waurá, kuikuro, kamayurá, parintintin, yanomami, paracanã e kajabi (HAKANI, 2008b, online).

Contudo, no Mapa da Violência de 2014, do Ministério da Justiça, valendo-se de dados de 2012, passou a considerar os números desses casos, o que fez com que o município de Caracaraí, em Roraima, de aproximadamente 19 mil habitantes, passa-se a ser considerado o mais violento do país, uma vez que, em um ano, foram registrados 42 homicídios lá, sendo 37 das vítimas índios recém-nascidos mortos pelas próprias mães. Estima-se que, no estado de Roraima como um todo, haja uma média de 210 homicídios para cada 100 mil habitantes, quando a média nacional é de 29 homicídios para cada 100 mil habitantes (TRADIÇÃO..., 2014, online).

Esses dados podem causar grande comoção e revolta na maior parte da sociedade, que considera o Poder Público como omisso em relação a esses casos, já que permite a continuidade da prática. Essa indignação se agrava quando o Brasil é signatário da Convenção 169 da Organização Internacional do Trabalho (OIT), que trata dos povos indígenas e tribais, promulgada no país pelo Decreto 5.051/2004. O item 1 do art. $8^{\circ}$ dessa Convenção explicita que a legislação nacional deve considerar os costumes e leis consuetudinárias dos indígenas e, no item seguinte, assegura a eles o direito de manterem seus costumes e instituições, desde que eles não desrespeitem os direitos humanos fundamentais presentes no arcabouço jurídico nacional e aqueles internacionalmente reconhecidos. 


\section{As práticas indígenas no âmbito penal brasileiro}

Como dito, há casos de mães indígenas que abandonam os filhos recém-nascidos nas matas, logo após o parto, quando eles nascem com alguma deficiência física ou mental, havendo casos de crianças nascidas nessas condições que foram mortas, por exemplo, sendo enterradas vivas. Analisando-se os dois tipos de situação do ponto de vista da legislação penal brasileira, pode-se levantar a hipótese de que se configuram nesses casos os crimes de abandono de incapaz, infanticídio ou, até mesmo, homicídio.

A Lei Federal n 6.001/1973, o Estatuto do Índio, prevê em seu art. $4^{\circ}$ que há três categorias de índios segundo seu nível de integração com a comunhão nacional: isolados, em vias de integração e integrados. Os primeiros são os que "vivem em grupos desconhecidos ou de que se possuem poucos e vagos informes através de contatos eventuais com elementos da comunhão nacional"; sendo os "em vis de integração" os que conservam práticas nativas, mas também possuem características dos demais setores da comunhão nacional e, por fim, os "integrados" se referem aos índios incorporados à comunhão nacional e reconhecidos no pleno exercício dos direitos civis, ainda que mantenham características típicas de sua etnia e cultura nativa.

Essa diferenciação é necessária para que se guie adequadamente a imputabilidade penal dos indígenas. Sendo assim, para que um indígena responda penalmente por um ato cometido, deve-se levar em consideração primordialmente seu nível de integração com a comunhão nacional. O Código Civil Brasileiro de 2002, art. 4º parágrafo único, coloca que a capacidade dos índios será regulada por legislação especial, diferente do Código Civil de 1916, que os colocava como relativamente incapazes.

O crime de infanticídio está previsto no art. 123 do Código Penal Brasileiro, em que o ato de matar o próprio filho sob influência do estado puerperal, durante ou logo após o parto, pode resultar em pena de detenção de dois a seis anos. O referido crime trata-se de um tipo 
especial de homicídio, e como o ato só é tipificado como infanticídio se for cometido no estado puerperal, somente à mãe biológica pode ser imputado o crime, desde que seja durante ou logo após o parto, não havendo um período fixo para o que se chama de estado puerperal (GRECO, 2011, p. 203-204).

Durante a gestação e o puerpério, a mulher experimenta mudanças hormonais significativas, bem como psicológicas, o que, em alguns casos, resulta na rejeição da genitora pelo seu filho, podendo contribuir para isso fatores sociais, familiares e também transtornos psiquiátricos preexistentes. A respeito disso, tem-se que:

O puerpério, também denominado sobreparto ou pós-parto, é o período de tempo que sucede o parto e, sob o ponto de vista fisiológico, compreende os processos involutivos e de recuperação do organismo materno após a gestação. Embora o caráter gradual e progressivo assumido por essas manifestações torne o período do puerpério um período de demarcação temporal imprecisa, é aceitável dividir o período que se sucede ao parto em Pós-parto imediato, do $1^{\circ}$ ao $10^{\circ}$ dia; Pós-parto tardio, do $10^{\circ}$ ao $45^{\circ}$ dia; e Pós-parto remoto, além do $45^{\circ}$ dia. Muitos estudos assumem como pós-parto os 12 meses que sucedem o parto. Além da relevância desses mecanismos fisiológicos para o restabelecimento do estado pré-gravídico da mulher, o puerpério é também caracterizado por marcantes mudanças em diversos outros aspectos da vida feminina, sejam eles conjugais, familiares, sociais ou profissionais (MONTENEGRO; REZENDE FILHO, 2013, p. 309, grifos dos autores).

Posto isso, é necessário considerar também que pode haver incidência de doenças mentais nesse período, as quais poderiam ensejar um ato de crueldade da mãe contra seu próprio filho.

Os transtornos mentais associados ao pós-parto, conforme classificação diagnóstica CID-10, encontram-se no capítulo de síndromes comportamentais associadas a distúrbios fisiológicos e fatores físicos (F50-F59) e incluem qualquer transtorno que tenha se iniciado até a sexta semana após o 
parto, mas podem também ser classificados como doenças mentais ou doenças do sistema nervoso central que complicam o puerpério (O99.3). No DSM-IV-TR, no capítulo de transtornos do humor, foi incorporada a classificação "com início no pós-parto" para caracterizar qualquer episódio iniciado até a quarta semana após o parto, podendo também ser utilizada para transtornos psicóticos breves (MONTENEGRO; REZENDE FILHO, 2013, p. 732).

Dentre os transtornos mentais que podem induzir uma mulher ao suicídio, tem-se a depressão pós-parto, que, em seus níveis mais graves, pode gerar na paciente "pensamentos obsessivos envolvendo violência contra a criança" e até mesmo delírios envolvendo o recém-nascido. Outra afecção seria a psicose pós-parto, que, dentre os sintomas provocados, verificam-se: o risco de suicídio, negligência infantil e, nos casos mais graves, infanticídio (MONTENEGRO; REZENDE FILHO, 2013, p. 733).

Para que se configure o infanticídio, não basta que a mulher esteja no estado puerperal, esse tem que, de fato, influenciá-la. Assim, se ela se encontrar nesse estado, mas não agir por influência dele e vier a matar o filho durante ou logo após o parto, ela responderá por homicídio. Já se a mulher encontrar-se em um estado de perturbação mental no puerpério, que afete incisivamente seu discernimento, levando-a a matar seu próprio filho, verificar-se-á a excludente de culpabilidade prevista no art. 26 do Código Penal, que isenta o agente que "por doença mental ou desenvolvimento mental incompleto ou retardado, era, ao tempo da ação ou da omissão, inteiramente incapaz de entender o caráter ilícito do fato ou de determinar-se de acordo com esse entendimento". Assim, haverá infanticídio quando a mulher o cometer sob influência do estado puerperal, porém de forma que ele não afete o entendimento dela sobre o caráter ilícito de seu ato, pois, se estiver afetado, aplicar-se-á tal excludente (GRECO, 2011, p. 205).

O Código Penal, em seu art. 21, coloca que a alegação de desconhecimento da lei não escusa o agente de responder pelo ato ilícito, mas, se o erro sobre a ilicitude do ato for inevitável, o agente pode 
ser isento de pena, e, se for evitável, a pena pode ser reduzida de um sexto a um terço. Por outro lado, o desconhecimento da lei pode atenuar a pena, conforme o art. 65, II, do referido diploma legal.

Em relação ao crime de abandono de incapaz, previsto no art. 133 do Código Penal, ocorre quando o agente abandona "pessoa que está sob seu cuidado, guarda, vigilância ou autoridade, e, por qualquer motivo, incapaz de defender-se dos riscos resultantes do abandono". Contudo, só haverá esse crime quando houver dolo de perigo, e não de dano. Posto isso, se o infrator tinha a intenção de provocar lesão corporal ou a morte da vítima, ele responderá por lesão corporal ou homicídio respectivamente (GRECO, 2011, p. 326).

Ao observarem-se casos concretos, analisando o Código Penal, em seu art. $121, \S 2^{\circ}$, incisos I, III e IV, infere-se que, alguns casos que muitos chamam de "infanticídio indígena" seriam, na verdade, homicídios qualificados. Isso porque a motivação para retirar a vida daquela criança mostra-se torpe, uma vez que é vil e provoca comoção na consciência média. Outra qualificadora seria o emprego de meio cruel, uma vez que, ao abandonar uma criança na floresta ou enterrá-la viva, causa um sofrimento desnecessário a ela, ou seja, é uma prática bárbara. $A$ terceira qualificadora verificável seria a aplicação de recurso que torna impossível a defesa do ofendido (BITENCOURT, 2011, p. 77-85).

Além disso, a pena pode ser majorada em 1/3 (um terço), já que o crime é doloso e praticado contra menor de 14 anos, conforme previsão do $\S 4^{\circ}$ do art. 121. Essa causa de aumento tem natureza objetiva e de aplicação obrigatória, sempre considerando que a vítima tenha menos de 14 anos na data em que a ação criminosa foi praticada, e não quando o resultado se consumou (BITENCOURT, 2011, p. 111).

Corroborando com a ideia de que esses casos podem ser tipificados como homicídios, vale salientar que as mulheres que abandonam seus filhos nas florestas ou os matam de outra forma, não agem, em sua maioria, por estarem sob efeito do estado puerperal, e sim para atender um costume secular de sua tribo, restando dizer que, nesses casos, ocorre infanticídio apenas etimologicamente (do latim infanticidium, 
que significa "assassinato de criança"), mas não do ponto de vista da tipificação penal brasileira.

\section{A proteção constitucional e infraconstitucional às crianças indígenas}

Da mesma forma como a incidência da imputação penal aos indígenas encontra limite nos textos constitucional e infraconstitucional, é cabível a discussão se as crianças e os adolescentes indígenas devem contar com a proteção da legislação nacional vigente.

As crianças e adolescentes que vivem no país, sem ressalvas, têm atenção e proteção especiais oferecidas pela Constituição Federal de 1988, pelo Princípio da Proteção Integral da criança. O art. 227 coloca que é dever da família, da sociedade e do Estado garantir a esse grupo etário, com absoluta prioridade, vários direitos, como à vida e à dignidade, assim como o de serem protegidas de todas as formas de negligência, discriminação, exploração, violência, crueldade e opressão.

Além disso, o Estado brasileiro assume em âmbito internacional o compromisso de reforçar a proteção à criança quando assina a Convenção sobre os Direitos da Criança, adotada pela Assembleia Geral das Nações Unidas em 20 de novembro de 1989, a qual foi promulgada no país pelo Decreto $n^{\circ} 99.710$, de 21 de novembro de 1990. Dentre as disposições desse texto normativo, está a obrigação de todos os Estados signatários garantirem os direitos presentes na Convenção a todas as crianças, sem distinção alguma, independentemente, inclusive, de origem étnica e deficiências físicas, segundo o item 1 do art. $2^{\circ}$.

A Lei Federal $n^{\circ}$ 8.069/1990, Estatuto da Criança e do Adolescente $(E C A)$, reforça o direito à vida (art. $4^{\circ}$ ) para essa parcela da população e garante que ela tem todos os direitos fundamentais inerentes à pessoa humana (art. $3^{\circ}$ ). Pela mesma norma, as crianças e adolescentes têm direito ao respeito, que se manifesta pela inviolabilidade de sua integridade física, psíquica e moral (art. 17). 
O ECA enfatiza, em seu art. 18, que todos têm o dever de zelar pela dignidade da criança e do adolescente, protegendo-as de qualquer tratamento desumano, violento, aterrorizante, vexatório ou constrangedor. Levando a esse enunciado para a realidade das tribos indígenas, as mães e todos os membros da comunidade em que vivem teriam, em tese, também têm o dever de abolir a prática do infanticídio, resguardando a integridade física de suas crianças, independentemente da condição em que nasceram e dos costumes da tribo. Sendo assim, também se torna obrigação do Estado interferir nas terras indígenas no sentido de levantar dados sobre essa prática e combatê-la, levando conscientização e, inclusive, aplicando penalidades para os que incorrerem no ato, se necessárias.

Portanto, a proteção que a Constituição Federal de 1988, a Convenção dos Direitos da Criança e o ECA oferecem à criança e ao adolescente é indistinta, não fazendo ressalvas para que povos nativos possam executar práticas tidas como cruéis e desumanas. No entanto, os referidos textos normativos carecem também de observar a realidade e a consciência dos povos nativos quanto a essa prática, uma vez que tais povos e seus costumes já existiam antes mesmo da construção da ideia de direitos humanos fundamentais.

\section{Conflitos acerca da prática do infanticídio indígena no Brasil}

A prática de infanticídio em tribos de diferentes etnias indígenas traz à tona uma discussão que envolve diferentes interesses e valores. A influência religiosa que incide na sociedade brasileira (sobretudo a cristã) e o ativismo de grupos de direitos humanos se confrontam com as opiniões de antropólogos e de entidades defensoras dos direitos indígenas. O ato de retirar a vida de uma criança recém-nascida é causador de repugnância e revolta em várias pessoas, mas, por outro lado, há um entendimento por parte de especialistas que não se deve interferir nos costumes indígenas, pois é um direito que lhes assiste preservá-los. 
A Constituição Federal de 1988 enuncia em seu art. $5^{\circ}$ que: "Todos são iguais perante a lei, sem distinção de qualquer natureza, garantindo-se aos brasileiros e aos estrangeiros residentes no País a inviolabilidade do direito à vida [...]". Vê-se, pela leitura desse trecho, que a inviolabilidade do direito à vida é indistinta, sendo direito de qualquer brasileiro. Sabendo que os índios são cidadãos brasileiros, resta 0 entendimento de que eles estão sujeitos aos mesmos mandamentos constitucionais e legais, inclusive no que se refere à incidência de sanções ao cometerem crimes.

Mas a questão não é tão pacífica quando se pensa que a proibição dessa prática advém de um juízo de valor da sociedade dita "civilizada", que possui modos de vida bem distintos dos silvícolas, os quais, muitas vezes, não estão a par dos processos políticos e jurídicos, até mesmo pelas limitações em termos de comunicação e convivência com outras etnias. É importante salientar que a cultura desses povos ainda vem de tempos imemoriais e, por isso mesmo, não é razoável simplesmente querer impor novos conceitos e comportamentos a eles.

A imposição de costumes aos índios com a finalidade de integrálos ao modo de vida da maioria da população também desrespeita direitos previstos constitucionalmente, já que no art. 231 , da Constituição Federal de 1988, são reconhecidos a organização social, costumes, línguas, crenças e tradições que lhes são próprias.. A liberdade de manifestação religiosa é reforçada pelo art. $5^{\circ}$, inciso $\mathrm{VI}$, da mesma Constituição Federal, a qual garante a inviolabilidade das práticas e locais de profissão de crença e culto.

\subsection{Conflito entre o direito à vida e o de autodeterminação dos povos indígenas brasileiros}

Como já mencionado, o direito à vida se conflita com o direito de autodeterminação dos índios em suas terras, e também com o direito à liberdade cultural e de crença que todos os cidadãos brasileiros possuem. A respeito dessa situação, foi aprovado em 2012, na Comissão de Constituição e Justiça (CCJ) da Câmara dos Deputados Federais, o 
Projeto de Lei $n^{\circ} 1057 / 2007$ (Lei Muwaji), que prevê a criminalização de condutas como o infanticídio, abandono de recém-nascidos e maustratos a crianças indígenas (BRASIL, 2007, online). Além disso, foi idealizada a Proposta de Emenda à Constituição (PEC) n 303, em 2008, a qual tornaria a inviolabilidade do direito à vida aplicável aos índios, fato que se justificaria pela necessidade de se combater o infanticídio de ordem étnico-cultural, abortos e homicídios de recém-nascidos nesse meio (BRASIL, 2008, online).

Assim, fica evidente que há uma movimentação em âmbito político para que haja uma intervenção no sentido de combater tais práticas dos povos indígenas, o que denota um claro caso de colisão entre direitos fundamentais, uma vez que os índios, titulares do direito à autodeterminação em suas terras e às manifestações culturais, podem enfrentar uma limitação concernente ao exercício de tais direitos (DIMOULIS; MARTINS, 2009, p. 153).

Essa celeuma torna pertinente a exposição das ideias do filósofo de direito alemão Robert Alexy sobre regras, princípios e valores. A diferenciação entre eles é de suma importância para entender quais elementos se colidem no caso de se proibir ou continuar permitindo o infanticídio indígena.

Utilizando-se do critério da generalidade, os princípios são normas com alto grau de generalidade, enquanto as regras são mais específicas. Ambos são normas, mas deve-se levar em consideração a tese de que há entre eles uma diferença gradual e, sobretudo, qualitativa. O que difere, de fato, princípios de regras, é que os primeiros são normas que podem ser aplicadas em diferentes graus diante das possibilidades fáticas e jurídicas que se apresentam. Por outro lado, uma regra é satisfeita ou não satisfeita, configurando-se como norma que determinam algo possível nos campos fático e jurídico (ALEXY, 2011, p. 90-91).

Os princípios possuem caráter deontológico, ou seja, exprimem mandamentos, sejam de proibição, permissão, dever ou direito a algo. Já os valores encaixam-se no âmbito axiológico, em que se reflete se algo é bom ou não, mas, dada tamanha subjetividade, a classificação 
de algo como bom ou ruim depende de muitos critérios (ALEXY, 2011, p. 145-146).

Já que os princípios envolvem uma relação de dever ser, são mais adequados à hermenêutica jurídica do que os valores, inclusive no que se refere à norma ser considerada constitucional ou não, bem como o modelo de princípios abre menor margem para interpretações inadequadas das normas (ALEXY, 2011, p. 153).

Diante do problema jurídico que se apresenta neste trabalho, ele pode ser analisado pelo viés da técnica do sopesamento, avaliando qual dos interesses em conflito apresenta maior peso no caso concreto, não sendo cabível que um dos princípios seja extirpado do ordenamento jurídico, nem por meio da introdução de exceção a um dos princípios, o que poderia fazer surgir no futuro uma regra que seria cumprida ou não (ALEXY, 2008, p. 95-96).

De acordo com o jurista e filósofo Hans Kelsen (2011, p. 131), o ordenamento jurídico é escalonado, sendo assim, partindo do pressuposto que princípios são normas, eles próprios são hierarquizados. Norberto Bobbio (1995, p. 48-49) reforça a ideia de escalonamento ao colocar que as normas de um ordenamento são dispostas hierarquicamente, cuja norma suprema, a que confere unidade ao ordenamento, é a norma fundamental. Analisando isso, é como se a resposta para o questionamento sobre a proibição ou não do infanticídio indígena estivesse respondida, sendo a resposta que tal prática deve ser proibida e a lei que previsse isso não seria inconstitucional, uma vez que o direito à vida e a dignidade da pessoa humana estão acima de qualquer outra norma de direito fundamental.

Entretanto, a questão não se encerra nisso, uma vez que surge a indagação sobre como dirimir as colisões entre princípios. Retomandose a técnica do sopesamento, ela seria um instrumento para tanto ao permitir investigar qual princípio pesa mais no caso concreto, contudo, é um meio que não se submete a um controle racional, dando azo a decisões judiciais eivadas pelo subjetivismo e pelos valores pessoais do juiz, representando um modelo decisionista. Esse modelo, contudo, pode 
ser contraposto por um sopesamento fundamentado, que será racional no momento em que o enunciado preferível possa ser fundamentado racionalmente. Antes de qualquer outra medida de solução para os conflitos entre princípios, contudo, deve haver uma definição de uma relação de precedências condicionadas (ALEXY, 2011, p. 163-165).

Complementando a ideia de Alexy, Dimoulis e Martins (2009, p. 155) expõem que há duas ferramentas para a solução de conflitos entre princípios constitucionais: a interpretação sistemática da Constituição Federal e o critério da proporcionalidade.

O critério da proporcionalidade se vale dos seguintes subcritérios para ser aplicado, segundo Dimoulis e Martins (2009, p. 178-201): licitude do propósito perseguido, licitude do meio utilizado, adequação do meio utilizado e a necessidade do meio utilizado. Os mesmos autores (2009, p. 201-202) fazem ressalvas quanto a um subcritério defendido por vários doutrinadores e tribunais, o da proporcionalidade stricto sensu, o qual se valeria de um sistema axiológico que envolve uma grande subjetividade por parte de quem o aplica, o que pode causar decisões equivocadas.

\subsection{Conflito entre lei, costumes e moral}

O costume, enquanto fonte do direito, caracteriza-se por dois elementos: um ato que se repete no tempo e uma "institucionalização que explica o processo a formação de uma convicção da obrigatoriedade e que se explicita em procedimentos, rituais ou silêncios presumidamente aprovadores" (FERRAZ JR., 2003, p. 242).

Para alguns estudiosos do direito, a lei é provida de generalidade, enquanto os costumes restringem-se a certos atos, grupos sociais ou localidades, mas nem sempre uma lei é dotada de generalidade, assim como há costumes genéricos (REALE, 2004, p. 156). A prática secular em algumas tribos indígenas de abandonar ou sacrificar recém-nascidos por ocasião de deficiência física ou mental, ou em casos de nascimento de gêmeos, é de fato um costume contra legem, ou seja, contrário à 
lei, já que o Código Penal veda a prática do homicídio (art. 121) e do infanticídio (art. 123).

A aplicação de costumes na seara penal brasileira é restrita, uma vez que o Princípio da reserva legal prevê que só existem crime e imputação de pena quando houver lei anterior que os definam. Assim, um costume não pode criar tipos penais, penalidades e muito menos revogar uma lei que assim proceda. Na esfera penal, o alcance de um costume pode ampliar as excludentes de antijuridicidade (ilicitude) e de culpabilidade (JESUS, 2009, p. 28-29). O art. $4^{\circ}$ do Decreto-lei $n^{\circ}$ $4.657 / 1942$ (Lei de Introdução às Normas do Direito Brasileiro) coloca os costumes, assim como a analogia e os princípios gerais de direito, como fonte indireta do direito, podendo o juiz aplicá-los somente em casos de omissão da lei.

O Direito representa o mínimo ético da sociedade, que seria o mínimo de comportamentos morais tutelados para que o direito cumpra seu objetivo de sobrevivência da sociedade, ou seja, por meio da harmonização de condutas no seio social (REALE, 2004, p. 42). No entanto, a moral e o direito são institutos diferentes, e nem sempre o direito abarca e protege todos os comportamentos morais socialmente aceitos, bem como nem sempre satisfaz todos os grupos que vivem em uma sociedade, uma vez que a moral é muito subjetiva, variando entre os indivíduos, as épocas e os lugares. Por isso, a prática do infanticídio indígena, que é considerado imoral por grande parte da "sociedade civilizada”, é moralmente aceitável para os grupos que o praticam.

Em todas as sociedades humanas, incluindo as sociedades indígenas pré-coloniais, há uma interligação entre todas as esferas de vida da comunidade: a política, a social, a religiosa, a econômica e a jurídica, mas esse caráter de indivisibilidade é conferido pelos pesquisadores como meio de otimizar os estudos deles e a percepção de certos setores sociais. No caso da esfera jurídica, ela está fundamentada em quatro princípios basilares: "a valoração dos interesses coletivos em detrimento dos individuais, a responsabilidade coletiva, a solidariedade e a reciprocidade". Além do mais, vale salientar que esse direito está 
intimamente atrelado à religião, aos costumes e à moral (COLAÇO, 1998, p. 112-114).

Portanto, vê-se nessa situação um conflito entre um direito consuetudinário (baseado nos costumes, praticado pelos indígenas) e o direito positivo, assim como há um confronto entre os pontos de vista acerca de o infanticídio indígena ser moralmente aceitável ou não, o que cria para os legisladores e doutrinadores jurídicos uma questão a ser solucionada quanto a qual dos dois lados o direito deverá proteger, ou qual seria a solução conciliatória para ambos os lados.

\subsection{Direitos das minorias no Estado Democrático de Direito}

No Brasil, com o advento da Constituição de 1988 houve o desenvolvimento e o aprimoramento do Estado Democrático de Direito, em que não se limita a satisfazer a vontade da maioria, mas também de visar grupos minoritários, conferindo-Ihes direitos e proteção contra o preconceito, como é o caso dos indígenas remanescentes na nação, inclusive dando maior suporte às previsões da já existente Lei Federal $n^{\circ} 6.001 / 1973$, o Estatuto do índio.

Como já dito, os nativos brasileiros foram vítimas de violência, perdas de suas terras e de processos de aculturação, e até hoje muitas tribos enfrentam problemas como os conflitos por terras contra latifundiários e garimpeiros, além da marginalização e a falta de acesso a serviços educacionais e de saúde em suas localidades. Esse panorama atual contraria em muito o texto do art. $2^{\circ}$ da Lei Federal $n^{\circ} 6.001 / 1973$, o qual garante aos índios a extensão dos benefícios previstos na legislação comum, sempre que possível, e o respeito aos valores culturais, tradições, usos e costumes deles.

Pelas disposições do Estatuto do índio, vê-se que os nativos não estão sujeitos à legislação comum da mesma forma que os indivíduos de outras etnias, ainda mais quando a Constituição Federal de 1988 garante-Ihes o direito de autodeterminação em suas terras, sem fazer 
ressalvas para que incidam sobre eles as penalidades previstas na legislação comum.

Outra questão a ser considerada seria a da prevenção, em que as organizações que atuam no âmbito indígena levantariam dados a respeito das ocorrências a fim de criar políticas que envolvam o diálogo com os habitantes das tribos para que eles não continuem praticando o infanticídio, até mesmo porque existem casos dentro das próprias tribos de pais que se negam a sacrificarem seus próprios filhos, ainda que isso destoe da tradição, como no caso Hakani, da etnia suruwaha, em que os pais preferiram se suicidar a tirar a vida da filha com problemas no desenvolvimento oral e motor (HAKANI, 2008, online). Mas, até mesmo uma política de conscientização, poderia significar uma tentativa de impor a cultura vigente no país àqueles que não congregam dela.

São comuns ao redor do mundo desrespeitos às práticas de povos autóctones, não só por parte de segmentos da sociedade civil, mas também por parte do próprio Estado:

[...] Provam suficientemente que poucos Estados, seja qual for sua localização, podem ter consciência limpa: dos subúrbios de Montreal aos de Sydney, passando pelas imensidões asiáticas, o aborígene quase sempre se encontra na parte mais baixa da escala. O Ocidente não é aqui o primeiro para ser incriminado, ainda que maneje de bom grado a raça como critério de discriminação. Mas, aqui também, a concepção do desenvolvimento econômico está na origem de muitos estragos irremediáveis. Não foi um acaso se, em numerosos locais do mundo, o renascimento dos movimentos identitários tenha sido a conseqüência direta das espoliações de terras e dos transtornos ecológicos provocados pela execução de grandes projetos de desenvolvimento (ROULAND, 2003, p. 311).

Diante de motivos pró e contra a liberdade de os indígenas manterem suas práticas seculares, surge um grande conflito jurídico a ser resolvido, mas, antes disso, deve-se analisar se há pertinência em criminalizar a conduta desses povos. Vê-se que a interpretação 
do direito provavelmente não oferecerá uma resposta satisfatória para essa situação, até mesmo porque não há hierarquia entre os princípios constitucionais, ficando essa escolha a cargo do legislador, que deve observar os valores sociais que estão em questão, o que perfaz uma decisão política (DIMOULIS; MARTINS, 2009, p. 169).

Entretanto, a decisão do Poder Legislativo pode também não estar de acordo com a Constituição, já que se trata de uma questão de proibir ou não o infanticídio indígena. Então, caso se tome conhecimento de um caso dessa prática, deverá ser feita a subsunção jurídica para aplicar todas as normas pertinentes. Caberá ao magistrado no caso concreto observar o contexto em que se executou tal ato, como, por exemplo, o nível de integração à comunhão nacional dos indivíduos que praticaram o infanticídio e as razões que os motivaram a isso, para então avaliar se vale a pena puni-los, sem desconsiderar os aspectos culturais intrínsecos à realidade dos praticantes (DIMOULIS; MARTINS, 2009, p. 169).

Sendo assim, qualquer interferência dos Poderes Legislativo e Judiciário para proibir e punir a prática pode estar contrária à Constituição, mas devem ser escutadas as vozes daqueles índios que não compactuam com esse ato em sua tribo, devendo o Estado oferecer-Ihes a assistência necessária para deixar a tribo e protegerem a incolumidade física dessas crianças, se necessário.

\section{Conclusão}

Diante de toda a explanação feita acerca da história, das motivações e dos conflitos sociais e jurídicos a respeito da prática do infanticídio em tribos indígenas, entende-se que é um problema eivado de tamanha complexidade que não possui uma decisão a ser tomada de imediato e carece de mais estudos antropológicos e sociológicos a respeito. Portanto, as conclusões sobre esse tema não se encerram aqui. 
Antes de o Poder Legislativo aprovar uma lei ou emenda constitucional para combater essa prática, ou não aprová-las, permitindo que os índios possam manter esse costume nos seus locais de vida, deve haver uma ponderação de valores morais e jurídicos da sociedade, bem como considerar a existência dos costumes indígenas antes mesmo da formação do Estado em terras brasileiras.

Na possibilidade de se criminalizar a prática do infanticídio em meio aos povos silvícolas, o Poder Judiciário deve levar em consideração os seguintes critérios: o nível de integração do índio infanticida à comunhão nacional, as motivações para o ato, as normas de convivência em sua tribo de origem e os possíveis impactos de aculturação e marginalização, caso aquele membro tribal seja penalizado. Portanto, deve-se levar em conta o caso concreto, e não simplesmente estender as penalidades aos índios, uma vez que nesse âmbito existe uma forma diversa de comportamento e de crenças em relação à sociedade, tornando necessário ponderar se é profícuo imputar-lhes alguma pena.

Não se pode desconsiderar que os enunciados constitucionais e infraconstitucionais conferem a todos os cidadãos brasileiros, indistintamente, direitos e deveres, como o direito à vida e à integridade física, e o dever de proteger a criança e o adolescente. Da mesma forma, quando uma mãe indígena abandona um filho recém-nascido ou ativamente acaba com a vida dele, ela tem, sem dúvidas, o dolo de matá-lo, e conta com a aceitação da tribo para isso.

Outrossim, o ato de matar crianças causa forte repugnância na maioria da sociedade, fomentando um discurso de indivíduos e instituições para que se proíba e que se puna essa prática, em que muitas vezes não há o que se falar em excludente de culpabilidade por motivo de doença mental, mas na possibilidade de aplicar a excludente de culpabilidade por conta do erro sobre a ilicitude do fato, já que os executores do ato o fazem por seguirem normas consuetudinárias antiquíssimas de seu povo, desconhecendo a ilicitude prevista no direito positivo brasileiro vigente. 
Não se objetiva com este trabalho afirmar que os índios são cidadãos à parte no país, pois isso seria uma visão etnocêntrica. Da mesma forma, não se pretende enunciar que os índios podem agir como Ihes apetecer, destarte, afirmar que, em suas terras, eles são altamente autônomos, ainda que imersos nas disposições jurídicas e políticas que regem e conferem integridade ao país. Nessa mesma linha de pensamento, não se pretende diminuir o valor da vida ou defender que as crianças devem estar completamente submetidas à vontade de seus genitores, mas fazer entender que até mesmo o direito à vida é relativo, ainda que os motivos que levam algumas etnias indígenas a permitir o assassinato deliberado de crianças sejam tidos como injustificáveis para a maioria da sociedade.

Sem dúvidas, o direito às manifestações de crença e de cultura não se sobrepõem ao direito à vida, mas o ponderamento desses direitos depende de parâmetros, os quais, portanto, devem ser aplicados segundo o referido nível de integração daquele indivíduo à comunhão nacional, pois não seria adequado fazer pesar nos autóctones os valores morais vigentes na sociedade brasileira, os quais são baseados em influências históricas e religiosas diversas.

Nesse sentido, a atuação do Estado em relação aos homicídios de crianças indígenas não deve ser no caráter de impor uma proibição ao ato, de punição os praticantes, nem mesmo de tentar inserir uma ideologia diferente para os nativos, mas oferecer proteção àqueles índios que não concordam com a prática e, por isso, não querem tirar a vida de seus descendentes. Portanto, se o que se deseja é a abolição do costume, é necessário que o movimento para isso venha dos próprios membros dessas etnias, pois só assim uma intervenção estatal para proibir essa ação será legítima.

\section{Referências}

ALENCASTRO, Luiz Felipe de. O trato dos viventes: formação do Brasil no Atlântico Sul. São Paulo: Companhia das Letras, 2000. 
ALEXY, Robert. Teoria dos direitos fundamentais. Tradução de Virgílio Afonso da Silva. 2. ed. São Paulo: Malheiros, 2011.

BITENCOURT, Cezar Roberto. Tratado de direito penal: parte especial: do crime contra a pessoa. 11. ed. São Paulo: Saraiva, 2011. v. 2.

BOBBIO, Norberto. Teoria do ordenamento jurídico. 6. ed. Brasília: Editora Universidade de Brasília, 1995.

BRASIL. Câmara dos Deputados. Proposta de Emenda Constitucional 303, 11 nov. 2008. Reconhece aos índios o respeito à inviolabilidade do direito à vida nos termos dos Direitos e Garantias Fundamentais da Constituição Federal de 1988. Disponível em: <http:// www.camara.gov.br/proposicoesWeb/fichadetramitacao?idProposic ao=415399 $>$. Acesso em: 16 maio 2016.

BRASIL. Câmara dos Deputados. Projeto de Lei 1.057, 11 maio 2007. Dispõe sobre o combate a práticas tradicionais nocivas e à proteção dos direitos fundamentais de crianças indígenas, bem como pertencentes a outras sociedades ditas não tradicionais. Disponível em: <http://www.camara.gov.br/proposicoesWeb/fichadetramitacao?idP roposicao=351362> . Acesso em: 16 maio 2016 .

COLAÇO, Thais Luzia. O direito indígena pré-colonial. In: WOLKMER, Antônio Carlos (Org.). Direito e justiça na América Indígena. Porto Alegre: Livraria do Advogado, 1998. p. 111-142.

DIMOULIS, Dimitri; MARTINS, Leonardo. Teoria geral dos direitos fundamentais. 2. ed. São Paulo: Revista dos Tribunais, 2009.

FAUSTO, Boris. História do Brasil. 13. ed. São Paulo: Editora da Universidade de São Paulo, 2010.

FERRAZ JR, Tércio Sampaio. Introdução ao estudo do direito: técnica, decisão, dominação. 4. ed. São Paulo: Atlas, 2003.

FUNAI. O Brasil indígena. Disponível em: <http://www.funai.gov.br/ arquivos/conteudo/ascom/2013/img/12-Dez/pdf-brasil-ind.pdf>. Acesso em: 16 maio 2016.

GEERTZ, Clifford. A interpretação das culturas. Rio de Janeiro: LTC, 2008. 
GRECO, Rogério. Curso de direito penal: parte especial. 8. ed. Niterói: Impetus, 2011. v. 2.

HAKANI. Hakani: uma menina chamada sorriso. 2008. Disponível em: < http://www.hakani.org/pt/historia_hakani.asp>. Acesso em: 7 abr. 2016.

HAKANI. Infanticídio nas comunidades indígenas do Brasil. 2008. Disponível em: < http://www.hakani.org/pt/infanticidio_entrepovos. asp>. Acesso em: 7 abr. 2016.

JESUS, Damásio de. Direito penal: parte geral. 30. ed. São Paulo: Saraiva, 2009. v. 1.

KELSEN, Hans. Teoria pura do direito. Tradução J. Cretella Jr e Agnes Cretella. 7. ed. São: Revista dos Tribunais, 2011.

LAPLANTINE, François. Aprender antropologia. São Paulo:

Brasiliense, 2000.

LARAIA, Roque de Barros. Cultura: um conceito antropológico. 24. ed. Rio de Janeiro: Zahar, 1932.

LOPES, José Reinaldo de Lima. 0 direito na história: lições introdutórias. 5. ed. São Paulo: Atlas, 2014.

MONTENEGRO, Carlos Antonio Barbosa; REZENDE FILHO, Jorge de. Rezende - Obstetrícia. 12. ed. Rio de Janeiro: Guanabara Koogan, 2013.

REALE, Miguel. Lições preliminares de direito. 27. ed. São Paulo: Saraiva, 2002.

ROULAND, Norbert. Nos confins do direito. Tradução Maria Ermantina de Almeida Prado Galvão. São Paulo: Martins Fontes, 2003. SOUZA, Laura de Mello e. O diabo e a terra de Santa Cruz: feitiçaria e religiosidade no Brasil colonial. São Paulo: Companhia das Letras, 1986.

TRADIÇÃO indígena faz pais tirarem a vida de crianças com deficiência física. Fantástico. Rio de Janeiro, Rede Globo, 7 de dezembro de 2014. Programa de TV. Disponível em: < http://g1.globo. 
com/fantastico/noticia/2014/12/tradicao-indigena-faz-pais-tirarem-vidade-crianca-com-deficiencia-fisica.html>. Acesso em: 1 maio 2016.

VENÂNCIO, Renato Pinto. Maternidade negada. In: PRIORE, Mary Del (Org.); BASSANEZI, Carla (Coord. de textos). História das mulheres no Brasil. 9. ed. São Paulo: Contexto, 2007. p.189-222.

Recebido em: 02/06/2016 Aprovado em: 09/03/2017 